\title{
Die Eerste Verhoudinge Tussen Boer en Brit.
}

Deur D. H. CILLIERS.

'n Mens hoor deesdae, veral van Engelse kant, weer heelwat omtrent die "gevoel," „rassehaat" e.s.m. wat daar dan tussen Afrikaans- en Engelssprekendes sou bestaan. Nou wil ek sommer dadelik sê dat dit

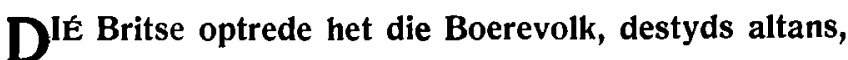
dan ook onherroeplik van die Engelsman vervreem en die Groot Trek'n noodsaaklikheid gemaak.

een van dié oordrewe en gevaarlike algemeenhede is wat maklik is om te beweer maar wat gewoonlik op onkunde en/of kwaadwilligheid berus en meestal ook nie bewys kan word nie, iets wat dikwels sommer uit die lug gegryp is en hoofsaaklik op papier bestaan-in Engels sou ek met 'n woordspeling wou sê: „On paper, more specifically, in the English papers." Trouens, as daar bewyse vir dié bewerings gevra sou word, glo ek dat die hele affêre op dieselfde bespotlike wyse sou doodloop as die wilde aansprake by die berugte "Swarte Ommegang" meer as 'n eeu gelede. Om die waarheid te sê, die beswadderingsveldtog teen die Afrikaner het nog nie veel in dié tyd verander nie. 
Om 'n saak na sy werklike waarde te beoordeel en 'n regte perspektief te verseker, is 'n breë historiese agtergrond daarvan te alle tye onontbeerlik. In hierdie artikel wil ek dus probeer om 'n vlugtige oorsig te gee van die eerste verhouding tussen Boer en Brit in Suid-Afrika tot ongeveer die jaar 1840.

Om hierdie wrywing en konflik, wat in wese een is tussen verskillende lewens- en wêreld- en Godsbeskouinge, behoorlik te verstaan, is dit vooraf nodig om net kortliks die stand van die twee blanke rasse by hul kennismaking te skets, d.w.s. aan die einde van die 18de en die begin van die 19de eeu.

Gedurende die anderhalwe eeu onder Hollandse bewind het hier aan die Kaap, as gevolg van verskillende geografiese, klimatologiese, geskiedkundige en ander omgewingsfaktore, uit die verskillende Europese elemente (hoofsaaklik Hollanders, Vlaminge, Duitsers en Franse) 'n nuwe aparte Boerevolk ontwikkel, destyds ongeveer 20,000 in getal en merendeels plattelands landbouers en boere, met sy eie selfgeskape Boeretaal, Afrikaans, en eie Boerevolksaard, soos verder geopenbaar in sy geskiedenis, Calvinistiese godsdiens en lewensbeskouing, sedes en gewoontes, kultuur en tradisies. 1)

Nadat die Afrikanervolk 'n 150 jaar lank hier wortel geskiet en ontwikkel het, is hul eerste en vreemde (Hollandse) bewindhebbers, sonder enige toedoen van hulle self, vervang deur 'n nóg vreemder owerheid, die Engelse, 'n nuwe bevolkingsgroep, hoofsaaklik stedelinge, amptenare, sakemanne en nyweraars, met 'n vreemde taal en geheel verskillende volksaard, agtergrond, geskiedenis, godsdiens en (liberalistiese) lewensopvatting, sedes en gewoontes, kultuur en tradisies.

Die Engelse het gekom as veroweraars, en hoewel baie aansienlik in die minderheid, het hulle uit die staanspoor ' $n$ kwetsende houding van meerderwaardigheid en neerbuigendheid teenoor die Afrikanerbevolking aangeslaan, wat van die begin af 'n kloof geskep het tussen die ou ingesetenes en die nuwe gesagvoerders en die eerste kieme van rassehaat gesaai het. Niemand minder nie as Lady Anne Barnard erken reeds in ' $n$ brief van 15 Oktober 1797 dat die neiging om die Boere te verag toe al "one great error in some of the English" was 2). Die onsimpatieke en dwase optrede van graaf Macartney, wat in Mei 1797 sy werk as eerste Engelse goewerneur hier begin het, genl. Dundas se negrofilisme en slegmaak van die Boere en sir George Yonge se wanbestuur het uit die staanspoor 'n vyandige gsindheid by die Afrikanergemeenskap geskep 3). Macartney se private sekretaris, Barrow, „formed his opinions of the Dutch before he could possibly have had any real knowledge of them, 
and in much the same spirit as that of his master, Earl Macartney, when he called the people of Graaff-Reinet savages and in the same breath said: "I neither know, nor can I learn where this Graaff-Reinet lies" " 4). Cory sê die land is inwendig verswak "partly by the Dutch feeling themselves despised and unduly severely treated by the Government," en tereg konstateer hy 5): "There can be but little doubt but that the history of South Africa would have been very different had the vicissitudes and disabilities of these people in the early days .... been better understood by those in authority at a distance."

Die vernaamste doel van die nuwe owerhede was om die Kaap so gou moontlik 'n Britse kolonie te maak en die burgers te verengels. As hulle meer geduld beoefen, meer mensekennis aan die dag gelê en taktvoller opgetree het, sou hulle ongetwyfeld baie gouer en verder in hulle doel geslaag het, maar deur hulle haastige, outokratiese, onredelike en onsielkundige optrede het hulle slegs die Boere tot verset uitgelok en op dié manier hul doel self verydel. Die eerste wat die Kaapse patriotte dwars in die krop gaan sit het, was die eis volgens 'n proklamasie van 7 Oktober 1795, later nog 'n paar maal herhaal, om die ced van trou aan 'n vreemde land en 'n vreemde koning af te lê, wat o.m. gelei het tot opstand, verbanning en voëlvryverklaring, 'n daad van dwang en geweld wat die vryheidsliewende Afrikaners 'n diepe afkeer van die Engelse regering gegee het 6 ). In die staatsdiens is ' $n$ uitskopbeleid gevolg en al die hoë betrekkings deur Engelse met groot salarisse gevul, daar was min vryheid van spraak, die regering is bestuur "on the strictest party lines," terwyl Macartney reeds op 24 Julie 1797 'n proklamasie uitgevaardig het waarvolgens Engels voortaan verpligtend sou wees in alle appelsake 7).

Teenoor hierdie politieke drywery aan dic cen kant is daar, veral op sosiale gebied, op allerlei subtiele maniere getrag om die Afrikaners vir die Engelse saak te wen. 'n Baie doeitreffende middel hicrtoc was die gereelde dans- en gewone partye deur Lady Ann Barnard gereël, waarheen dan al die vooraanstaande Afrikaners in grocpies genooi is. Spoedig kon sy dan ook skrywe: "(I) have had all the respectable Dutch families round in turn to dinner," met die gevolg dat "Mr. Barnard and I are very great favourites of the Dutch inhabitants" 8). Ondertrouery, waarmee die kern van die volkslewe, die huisgesin, in sy wortel aangetas is, het dan ook nie uitgebly nie, want reeds op 10 November 1798 skrywe sy: „Our officers have of late been marrying these Dutch vrouws at a great rate ..."9) Onder hierdie hoë lui wat in allerlei possies gestop is, was daar dan ook gou 'n klomp oorlopers, en dit het nie lank geduur nie of baie van hulle was grotendeeis Engelsgeoriënteerd 10). 
Die koms en metodes van die Engelse het dus nie alleen gelei tot rassewrywing tussen Boer en Brit nie maar was ook die regstreekse oorsaak van die ongelukkige en betreurenswaardige verdeeldheid onder die Afrikaners self, wat tot vandag toe nog soos 'n kanker in ons volkslewe voortwoeker. Trouens, dis 'n belangrike geskiedkundige feit, sielkundig ook heeltemal verklaarbaar, dat in elke land ter wêreld waar die Engelse invloed hom laat geld het, die gevolge nog altyd was onenigheid, wrywing, rassegevoel, klasseverdeling volksverdeeldheid, inkruipery, verraad, ontworteling, uitbuiting, onderkruiping, onderdrukking, en selfs burgeroorlog. Die jongste verwikkelinge in die Midde-Ooste is daar ' $n$ sprekende voorbeeld van. Dis ongelukkig óók waar dat dié kulturele verraad gewoonlik die eerste en die meeste onder die meer vooraanstaande groepe voorkom en dat die sgn. mindergegoede ,agterklasse” of „backvelders" die mees behoudende en kultuurvaste element in die volkslewe is. Só was dit byvoorbeeld in Vlaandere, in lerland, in Wallis, in Skotland en ook by ons. In ' $n$ groot mate is ons platteland dus ook nog die behoud van die Afrikaner se kultuur.

Nadat die lot van die Kaap deur die vrede van 13 Augustus 1814 finaal verseël was, is die poging om die land vir goed 'n Britse kolonie te maak met mening aangepak. Dit was veral lord Charles Somerset wat in die eerste kwart van die 19de eeu (nes later lord Milner aan die begin van hierde eeu) die Afrikaner wou onderploeg. Een van die middele hiertoe was die sentralisasie van die landsregering. Alle administratiewe, wetgewende, uitvoerende en selfs regsprekende gesag is naamlik in die goewerneurs gekonsentreer en alle Bataafse amptenare vervang deur Engelse of deur koloniale Hollandssprekendes wat reeds onder die eerste tydelike Britse bewind gedien het. Hoewel Somerset bewus was van die wrywing wat dit sou veroorsaak en hoofregter sir J. A. Truter ook daarop gewys het dat die stap teen die bestaande wette van die kolonie sou indruis, is die burgersenaat asook die howe van landdros en heemrade ontbind ,in compliance with the commands of His Majesty." In plaas van eersgenoemde is op 2 Mei 1825 'n (slegs) Adviscrende Raad ingestel bestaande uitsluitlik uit amptenare, terwyl die landdroste deur magistrate vervang is Trouens, die hele Romeins-Hollandse regstelsel is gewysig en geleidelik verengels. Graaf Bathurst se opdrag aan Somerset was naamlik om die howe te hervorm ,to provide for the contemplated use of the English language, to be followed, as may naturally be hoped, by the gradual assimilation of Colonial Law to the more liberal and enlightened maxims of British Jurisprudence" 11). Eers 'n 60 jaar later, naamlik deur Wet nr. 21 van 25 Julie 1884, sou Hollands weer in die howe toegelaat word 12). 
Geen wonder nie dat Theal skrywe: „The system under which the colony was henceforth ruled was virtually a despotism pure and simple" 13).

'n Tweede metode was immigrasie op groot skaal. In verband met die oogmerke van die 1820-setlaars-skema skrywe die redakteur, Pringle, in "The South African Journal” van 1824 o.m.: "The most obvious of these were the engrafting of a British upon the Dutch population of this Colony .... The English habits would have been gradually communicated to the inhabitants ..."14). En Cory (a.w., I, p. 403) skrywe dat hulle koms die hele karakter van die Oostelike Provinsie sou hervorm en „stamp it as more essentially British." C. J. F. Bunbury skrywe in sy "Journal of a Residence at the Cape of Good Hope" dan ook (p. 52) dat reeds ' $n 20$ jaar later, d.w.s. teen 1838, die oorgrote meerderheid van die name van winkeliers in Kaapstad, in die Westelike Provinsie, die meeste advertensies en firmas ens. al Engels was „and one meets English faces at every town." Ondanks die denasionaliseringsmotief agter die hele skema het die Boere die nuwe intrekkers baie hartlik verwelkom, hulle al die nodige hulp verleen, en jare lank in vrede met hulle Engelse landsgenote saamgelewe. Mnr. John Bailie, een van die vooraanstaande 1820-setlaars, getuig byvoorbeeld: „Our reception by the Dutch inhabitants was that of brother meeting brother after long and distant separation" 15). Ook luit.-kol. John Graham getuig van die gewilligheid en goeie gees by die Boere wat hom moes help teen die kaffers op dic grens. 16) Die hartlikheid wat by die afskeid voor die Trek bv. op Grahamstad geheers het, is welbekend 17).

Ook op onderwysgebied is, 'n sentralisasie-, immigrasie- en anglisasiebeleid gevolg om die Afrikaner van sy wortels af los te ruk. Die Bybel- en Skoolkommissie is byvoorbeeld totaal veronagsaam en alle skole onder die direkte beheer van Somerset geplaas, waardeur die Afrikaner alle seggenskap in die opvoeding en onderwys van sy kind ontneem is. Somerset het sy plan ,of having all the schools in the Colony conducted by English masters" aan graaf Bathurst, die Minister van Kolonies, voorgelê, wat hom daarin ook hartlik ondersteun het, „as affording the best means of making the English language more general in the Colony and improving the manners and morals of the People" 18). Daarop het hy aan ds. Thom van Caledon, wat toe met verlof in Engelond was, opgedra om sodanige onderwysers uit te soek, en vroeg in 1822 het die eerste groep van ses „British-born subjects," goedgekeur deur die "Home Government” o.m. op grond van hul „Loyalty to the King and Constitution," na Suid-Afrika vertrek, „under the designation of Instructors of the English Language" . . . the Plan of Instruction to 
be the .... British System" 19). Dié aantal is spoedig aansienlik vermeerder 20). In Desember 1821 skrywe Henry Ellis, ondersekretaris van die Kaapse regering, 'n brief aan Goulburn waarin hy aandring op die verbreking van die band tussen die Kaap en Holland, wat tot dusver nog bly bestaan het deur die studie aldaar van studente in die regte en die godgeleerdheid en deur ondertrouery; en hy gee verder aan die hand dat die onderwysfonds, wat tot dusver feitlik uitsluitlik deur die Hollandse predikante behartig was, liewer moet aangewend word vir 'n skool „on the principle of our public schools in England," waarvan een van die grootste voordele sou wees "the more rapid assimilation to the institutions and manners of Great Britain" 21).

Op 5 Julie 1822 het Somerset se berugte proklamasie verskyn waarvolgens Engels binne 5 jaar die enigste offisiële landstaal sou wees. Terselfdertyd is sy nuwe skema van vry Engelse staatskole ingestel met Engels as voertaal (selfs vir godsdiensonderwys) en vak en met hoegenaamd geen voorsiening vir Hollands nie. Volgens die Engelse se liberalistiese rassebeskouings is dié skole verder deur blank én gekleurd bygewoon, en ,any attempt at making a distinction between the two races met with the frowns of the Government" 22 ).

Teenoor die inkorting en veronagsaming van die blanke Afrikaners se regmatige aansprake enersyds is dié van die nie-blankes andersyds deur die Engelse bewindhebbers gekonsolideer en uitgebrei. So is daar byvoorbeeld geleidelik verdrae met die inboorlinghoofde aangegaan aan wie jaargelde, gewere en ammunisie verskaf is om as 'n goedkoop polisie te dien teen die Boere 23). Selfs die Engelse se godsdiens het verbroedering met die nie-blankes beoog. So was dit byvoorbeeld die gewoonte van enige sendelinge van die "London Missionary Society" om op feesdae 'n optog van blanke en gekleurde kinders "hand-aan-hand" deur die strate te laat marsjeer met vaandels voorop waarop die opskrif gepryk het: EX UNO SANGUINE 24). Hierdie negrofilisme en assimilasiepolitiek, wat in direkte teëstelling met die Afrikaner se standpunt van apartheid was, die voortrek en beskerming van die "onskuldige swartes" aan die een kant, en daarteenoor die skandalige beskuldigings teen en beswaddering van die Boere deur die Engelse sendeling, wat gedien het as die oé, ore en mond van die inboorlinghoofde, moes noodwendig lei tot agterdog teen en afkeer van die vreemde, oorsese bewind en tot wrywing tussen Engelsman en Afrikaner in hierdie land, 'n ongelukkige toestand wat selfs vandag nog in sekere mate heers; trouens, die Engelse pers tokkel ná meer as 100 jaar nog steeds op dieselfde snaar.

Dis dan ook geen wonder dat die Afrikaners hierdie denasionaliserende skole geboikot en hul eie private skooltjies gestig het nie 25). 
Ewe-as lord Charles Somerset en sy opvolgers enersyds besef het dat hulle die Hollandse taal sal moet verban, nie alleen uit die skool nie maar ook uit die staatdiens, die kerk en die samelewing, alvorens hulle die ou inwoners doeltreffend kon verengels, net so het die Afrikaners andersyds weer onbewus gevoel dat hul kerk, skool, taal en nasionaliteit ' $n$ onlosmaaklike, organiese eenheid vorm wat ten alle koste beskerm, verdedig, gehandhaaf en bestendig moes word as hulle nie as volk wou ten onder gaan nie.

Maar selfs in sy kerklik-godsdienstige lewe is die Afrikaner geen vryheid gelaat nie. Ook hier is die drie beproefde middele, nl. sentralisasie, immigrasie en anglisasie, toegepas, want daar is maar alte deeglik besef dat ook hierdie vesting verower sou moes word om die Afrikaner volkome en finaal te ontwortel.

So het sir David Baird reeds pas ná sy aankoms in 1806 al 'n Commissaris Politicq vir kerklike sake aangestel, wat o.m. tot gevolg gehad het dat die kerkraad iemand moes huur en betaal om sy korrespondensie met die regering te vertaal. Die goewerneur het hom selfs die outokratiese reg aangematig om uit die opgestelde dubbeltalle self sekere kerkraadslede aan te stel, waardeur die hele wese van dié amp en die kerk geskend is en waarteen die kerkraad dan ook geprotesteer het 26). Caledon het dit in 1811 goed gedink om die kerkraad aan te spreek oor dié se "disposition .... to oppose the orders and wishes of His Majesty's Government" en hulle terdeë laat verstaan dat hy nie die kerk sou toelaat "to separate itself from the Government nor yield my right to control over it as well as over every other department" 27). Die predikante moes selfs van die owerheid verlof vra om 'n sinode te mag hou asook goedkeuring vir die beskrywingspunte, en die sinodale besluite moes eers deur die goewerneur en die "home Government" bekragtig word om geldig te wees. Eers deur ordonnansie nr. 7 van 8 November 1843 is aan die kerk die reg verleen om sy eie interne sake te reèl. 28).

Met die aankoms van Somerset se ingevoerde Skotse predikante vanaf 1818 word die verengelsing van die Afrikaner se kerk met meer mening aangepak. So was die beskrywingspunte van die kerkraad van Caledon vir die eerste sinode (2 Nov. 1824 vlg.) almal in Engels opgestel, een waarvan gevra het dat 'n kategismus vir kinders opgestel word „and that the same be printed in both the Dutch and English languages and which Catechism shall be universally used by the members of the Reformed Church." 29) Reeds vroeg in die sinodejaar het eerw. Alexander Smith, een van die ingevoerdes, pas ná sy aankoms in Julie 1823 aan die gemeente van Uitenhage die nagmaal in Engels bedien, waarop „Het 
Ned. G.H. Tijdschrift" van Mei-Junie 1824, p.156, skrywe dat dit die eerste maal in die geskiedenis van S.A. is "dat het bondzegel, in eene gereformeerde kerk in deze Kolonie, in de Engelsche taal is uitgereikt." Op die eerste sinode is selfs al die wenslikheid uitgespreek om die Hollandse Kerk 'n deel van die Skotse Kerk te laat uitmaak 30).

$\mathrm{Na}$ aanleiding van die derde sinode (1829) het die CommissarissenPolitiek dit in hul verslag van Mei 1830 as hul oorwoë mening uitgespreek dat die plan van die eerste sinode vir 'n Teologiese Seminarium aan te beveel is maar dat, ,a general knowledge of the English Language being of great moment for the Colony," dit verpligtend moes wees „that as well .... Clergymen, as ... . Teachers, must be competent to preach and teach as well in the English as in the Dutch language, and that no Minister ordained in this Colony shall be admitted to the Pulpit without his being bona fide enabled to comply with such stipulation" 31 ).

Die gevolg was dat predikante wat in Holland gestudeer het, nie deur die regering geplaas is nie, en toe die Kaapse ring in 1836 die saak onder die aandag van die owerheid bring, het lord Glenelg geantwoord dat Afrikaners alleen kon aanspraak maak op aanstelling mits hulle in staat was „at least to perform divine service in the English as well as the Dutch Language" en mits hulle 'n deel van hul opleiding in Engeland gehad het 32).

Uit die voorafgaande is dit dus duidelik dat alle moontlike kragte (staatsdiens, skool, kerk, handel, nywerheid ens.) ingespan is om die Afrikaner deur ekonomiese dwang en andersins genadeloos te denasionaliseer. Dieselfde regering wat enersyds, tot stoflike nadeel van die Boere, die fisieke slawerny van 'n swart en vreemde barbareras afgeskaf het, het in die plek daarvan, en tot die Afrikaner se geestelike ondergang, deur middel van sy verengelsingsbeleid en totale veronagsaming van die Afrikaner se historiese verlede, volksaard, volksbelange, lewensbeskouing en ideale, gestel die psigiese verknegting van 'n beskaafde blanke sustervolk, onteenseglik ' $n$ misdaad in sy wese veel erger, in sy berekendheid veel fyner en wreder, in sy omvang veel wyer en dieper ingrypend, in sy uitwerking veel doeltreffender en verwoestender.

Dié Britse optrede het die Boerevolk destyds altans, dan ook onherroepelik van die Engelsman vervreem en die Groot Trek 'n noodsaaklikheid gemaak. Tereg skrywe dr. E. G. Malherbe: 33)

... owing to the total disregard of the language of the majority of the people and to the injudicious tamperings with local institutions and ways by a tactless and unsympathetic Government, this period saw the unfortunate beginning of an antagonism towards English rule and the 
English language which has retarded the progress in general, and the educational progress in particular, of the two white races in South Africa up to very recent times; and many of the educational problems that emerged subsequently can be traced to this very period.

J. A. Froude sê: 34)

"If we had been wise, we should have made allowance for the circumstances under which the Cape had come into our hands; we should have tried to reconcile the Dutch to an alien rule, by exceptional consideration. We did make an exception, but not in their favour. We justified our conquest to ourselves by taking away the character of the conquered ...."

Geen wonder dat maj. Charters dan ook reeds in 1840 in 'n mededeling aan die "United Service Journal" die feit moes betreur dat daar geen vriendskaplike omgang meer tussen die twee blanke rasse in Kaapstad en elders bestaan nie, terwyl biskop Grey 'n paar jaar later ook erken: „The two races, in fact, do not associate. The English look on them with contempt, and they feel their inferiority and are jealous of those who are their superiors." 35 )

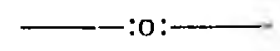

\section{VERWYSINGS.}

1) Vgl. o.m. Theal: History of S.A., 1652-1795, I. p. 365; II, pp. 319-349; S. F. N. Gle: Geskiedenis van S.A., I, pp. 68, 253-254; II, pp. 11-33.

2) South Africa a Century Ago, p. 38. Vgl. ook F. R. Statham: Paul Kruger and his Times, p. 16.

3) Vgl. Cory: The Rise of S.A., I, pp. 10-71; Gie, a.w., II, pp. 63, 65-66.

4) Cory, a.w., I, p. 73; Gie a.w. II, p. 12.

5) Cory, a.w., I. pp. 72, 97. Vgl. ook A. Moorrees: Die Ned Geref. Kerk in S.A., 1652-1873, pp. 440-442.

6) Vgl. o.m. Lady Anne Barnard, a.w., pp. 14, 38, 43, 45; Theal: Records of the Cape Colony, I, pp. 178-179; II, pp. 92, 108-109; III, p.2; V, pp. 1, 5-9, 16, 28, 44 vlg., 100-101; Hist. of S.A., 1795- 1834, pp. 9-14, 37-42, 52-54, 160164; Gie a.w. II pp. 66-70.

7) Theal: Records II, 128; V, pp. 26-27.

8) Lady A. B., a.w., pp. 8, 27, 28, 38, 108-109. 
9) A.w. p. 80; ook pp. 73-75. Dr. W. J. B. Pienaar (,Die Britse Stamverwantskap en Kulturele Beïnvloeding," in C. M. v.d. Heever en P. de V. Pienaar: Kultuurgeskiedenis van die Afrikaner, I, p. 231) bereken dat daar tussen 1795 en 1806 al ongeveer 30 huwelike tussen Engelse en Afrikaners plaasgevind het, en tot 1820 omtrent 150 .

10) Gie, a.w., II, p. 63; W. J. B. Pienaar, a. art., p. 223; Dorothy Fairbridge. Lady Anne-Barnard at the Cape, p. 34.

11) Theal: Records, XIV, pp. 371-373, 452-543; XV, p. 32; XXI, pp. 236, 407; XXIII, p. 50; XXVIII, p. 15; XXVIII, p. 15; XXXII, pp. 7, 254-261; XXXIV, pp. 248-252, 262-264, 274-292, 508, 510-516.

12) Vgl. G. W. Eybers: Select Constitutional Documents, pp 133-134, 136.

13) Hist. of S.A., 1795-1831, pp. 133-134.

14) Onderstreping van my.

15) Cory, a.w., IV, p. 255.

16) A.w., I, p. 243.

17) Vgl. Cory, a.w., III, pp. 401-402.

18) P. S. du Toit: Onderwys in Kaapland (1652-1939), p. 69. Onderstreping van my.

19) Theal: Records, XIV, p. 97; Report S.A.E., 1853, p.3. Dié ses was Archibald Brown (Stellenbosch), James Rattray (Tulbagh). Robert Blair (Caledon), William Robertson (Graaff-Reinet), William Dawson (George), en James Rose-Innes (Uitenhage).

20) Vgl. Theal: Records, XIX, p.61; J. C. Golding: An Epitome of the State of Education . . . . at the Cape of Good Hope, App. 2, pp. 28-37.

21) Theal: Records, XIV, pp. 183-187. Onderstreping van my.

22) Cory, a.w., IV, p. 210.

23) A. W. Eybers, a.w., pp. xxxi, 26-28; J. A. Wiid; „Die Geskiedenis van die Afrikaner," in C. M. v.d. Heever en P. de V. Pienaar, a.w., I, p. 66.

24) Theal: Hist. of S.A., 1834-1854, p. 205.

25) Vgl. bv. Report Education Commission, 1863, p. xxviii, par. 54; App. III, pp. 12-13; App. V, pp. 51-52, 78-79; Theal: Records, XIX, pp. 498-500; E. G. Malherbe: Education in S.A., 1652-1922, pp. 68, 82-83.

26) A. Dreyer: Boustowwe vir dle Geskiedenis van die N.G. Kerke in S.A., pp. 88-91, 99-119, 122 v.m.

27) A.w., pp. 133-134.

28) A.w., pp. 175-176, 195-197, 306.

29) A.w., p. 191.

30) A.w., pp. 262-263; S. P. Engelbrecht: Geschledenis van de Ned. Herv. Kerk in Z.A., p.11, A. Moorrees: Die Ned. Geref. Kerk in S.A., 1652-1873, pp. 564-566; Cory, a.w., III, p. 103.

31) A. Dreyer, a.w., p. 322.

32) A. Dreyer, a.w., p. 385.

33) „Education in South Africa," in Year Book of Education, 1932, p. 629.

34) Oceana, p. 38.

35) L. E. Neame: Genl. Hertzog, p. 29. Vgl, ook bv. H. C. Armstrong: Grey Steel, pp. 18, 19; N. J. v.d. Merwe: M. T. Steyn, I, p. 38. 